\title{
transformações da agricultura brasileira desde 1950^
}

\section{changes in the brazilian agriculture since 1950}

\author{
Francisco Vidal Luna $\star \star$ \\ Faculdade de Economia, Administração e Contabilidade, Universidade de São Paulo, São Paulo, \\ São Paulo, Brasil
}

Herbert S. Klein $\star \star \star ~$

Departamento de História, Universidade Columbia, Nova York, Nova York, Estados Unidos

\section{RESUMO}

$\mathrm{O}$ artigo analisa o processo de modernização da agricultura brasileira. Iniciado em meados do século $\mathrm{XX}$, permitiu ao país transformar-se em um dos mais importantes produtores e exportadores agrícolas do mundo, ocupando posição de destaque em inúmeros produtos, como soja, suco de laranja, açúcar, carnes, café, etanol, milho e algodão. Apesar da modernização do agronegócio brasileiro, subsiste um amplo segmento de propriedades de baixos rendimentos físico e econômico, em que vivem milhões de agricultores dedicados a uma atividade de mera subsistência.

Palavras-chave: Agricultura. Modernização. Brasil.

\begin{abstract}
The article analyzes the process of modernization of Brazilian agriculture. Begun in the mid-twentieth century, this modernization has enabled the country to become one of the world's leading agricultural producers and exporters, occupying a prominent world position in many products such as soy, orange juice, sugar, meat, coffee, ethanol, corn and cotton. Despite the modernization of Brazilian agribusiness, a large segment of lowincome fiscal and economic properties subsists, which incorporates millions of farmers dedicated to a subsistence activity.
\end{abstract}

Keywords: Agriculture. Modernization. Brazil.

O surgimento do Brasil como grande produtor agrícola mundial no final do século XX é um dos desenvolvimentos mais importantes da história moderna. As transformações que ocorreram na agricultura brasileira desde meados do século passado, permitiram que o Brasil deixasse de ser um importador de alimentos, concentrado na exportação de apenas um produto, para se tornar o maior exportador líquido de

\footnotetext{
* Submetido: 7 de dezembro de 2018; aceito: 5 de setembro de 2019.

$\star \star$ Professor assistente doutor aposentado da Faculdade de Economia, Administração e Contabilidade da Universidade de São Paulo.E-mail: fvluna1@gmail.com

$\star \star \star$ Professor emérito de História da América Latina, Departamento de História, Universidade Columbia.E-mail: hsk1@columbia.edu
} 
alimentos do mundo e o terceiro maior produtor e exportador agrícola depois dos Estados Unidos e da União Europeia. O país situa-se entre os 5 maiores produtores mundiais de 36 produtos agrícolas e é o principal exportador mundial de soja, suco de laranja, açúcar, carnes, café, tabaco e etanol. Além disso, é o segundo maior exportador de milho e o terceiro de algodão. Na segunda década do século XXI, vendeu quase 300 produtos agrícolas para mais de 200 países (Ministério da Agricultura, Pecuária e Abastecimento, 2012, p. 20; Klein; Luna, 2019).

Até meados do século XX, o Brasil caracterizava-se como um país agrícola, com a produção de ampla variedade de produtos agropecuários, mas elevada concentração na pauta de exportações. As exportações de açúcar e café foram as mais representativas, com destaque para o algodão, a borracha e o cacau em alguns períodos. A produção, tanto dos produtos de exportação como os destinados ao mercado interno, realizava-se de forma tradicional, com baixa tecnologia, pouca utilização de máquinas e equipamentos e a renovação constante das novas áreas de plantio, com a incorporação sistemática de solos virgens, pelo rápido esgotamento dos solos utilizados. O trabalho era pouco qualificado, o crédito agrícola mínimo e uma fronteira móvel em terras virgens era o principal insumo para a agricultura. Essa agricultura tradicional ocorria em uma estrutura agrária muito concentrada. A grande propriedade rural, que servia como reserva de valor, e o latifúndio improdutivo eram características marcantes da estrutura agrária no Brasil. A agricultura absorvia mais da metade da população economicamente ativa, com baixa produtividade, e sem os benefícios da legislação trabalhista que protegia os trabalhadores urbanos. A produção concentrava-se em cerca de dez cultivos, que representavam três quartos do valor da produção. Embora o número de fazendas e terras em produção estivesse em expansão desde a década de 1920, era reduzida a proporção de pastos e florestas plantadas, o maquinário tinha ainda uso limitado e os fertilizantes e inseticidas eram pouco utilizados. Em 1960, as dez principais culturas ocupavam $25 \mathrm{mi}$ lhões de hectares, com o milho ocupando a maior área (7,3 milhões de hectares), seguido pelo café, algodão e arroz.

Entre 1940 e o início da década de 1960, a estrutura deficiente da agricultura era identificada como o principal impedimento ao desenvolvimento do país, restringindo a das forças produtivas e permitindo a sobrevivência de uma estrutura de poder atrasada e conservadora. Como 
se acreditava que a alta concentração de propriedade da terra e o latifúndio improdutivo impedissem a modernização da agricultura, propunha-se a reforma agrária como solução.

O governo militar que assumiu em 1964, embora contrário ao processo de reforma agrária, concordava com o diagnóstico de atraso da agricultura brasileira, e da necessidade de profundas reformas. Como resultado, desenvolveu um amplo conjunto de reformas, classificado como modernização conservadora, pois não incluía alterações na estrutura de propriedade da terra nem desafiava o poder das elites rurais, embora exercesse pressão sobre a terra improdutiva. Ao invés de adotar processos que interferissem diretamente na estrutura da posse da terra, como forma de superar o atraso da agricultura brasileira, o novo governo decidiu estimular o processo de modernização da agricultura. Ao mesmo tempo, combateu os movimentos sociais que exigiam a reforma agrária e promoveu um amplo processo de colonização de agricultores pobres e sem terra, sem alterar na essência a estrutura agrária.

O governo via na agricultura uma importante fonte de pressão inflacionária pelas deficiências na oferta de produtos agrícolas no mercado interno e ao mesmo tempo entendia que a redução no custo dos alimentos seria essencial para conter as pressões salariais existentes. Assim, procurou demonstrar que a agricultura atendia aos estímulos capitalistas (Pastore, 1973), e a deficiente oferta de alimentos não exigia transformações no campo, mas a modernização da agricultura, seguindo experiências bem-sucedidas em outros países, como a chamada Revolução Verde (Gonzáles, 2006; Perkins, 1997). A modernização da agricultura deveria desempenhar papel crucial no processo de substituição de importações, pela oferta abundante e barata de alimentos e matérias-primas, e também pela geração de excedentes exportáveis, contribuindo para o equilíbrio da balança comercial. Assim decidiu fornecer crédito maciço aos produtores rurais para promover a modernização da agricultura, e ampliar a mecanização e o uso de insumos modernos, como sementes, fertilizantes e defensivos. A mecanização também teria um efeito positivo de liberar mão de obra da agricultura tradicional para a indústria em expansão e, ao mesmo tempo, deveria ampliar o seu mercado.

Como a modernização era feita com máquinas, equipamentos e insumos nacionais relativamente caros, pois eram protegidos internamente pela substituição de importações, era necessário criar um sistema 
de subsídios compensatórios e de proteção agrícola, como a política de garantia de preços mínimos (PGPM). Para maior controle sobre o comportamento da oferta e maior estabilidade de preços, desenvolveu-se também um abrangente sistema de formação e administração de estoques reguladores. Ademais, criou-se um amplo sistema de crédito público e privado (SNCR), orientado para a aquisição de máquinas e equipamentos e estimular a utilização de insumos modernos na agricultura. Esse sistema beneficiou em particular os agricultores comerciais interessados e com potencial para se modernizarem e paralelamente expandia-se o mercado para a indústria local. Ademais, a ampliação das indústrias processadoras de produtos agropecuários, como frigoríficos, e soja e suco de laranja, formava o complexo agroindustrial, de fundamental importância para a economia brasileira, embrião do atual complexo do agronegócio (Dias;Amaral, 2000; Delgado, 2001,p. 157-172;Alves, 1983; Melo, 1985, p. 86-111).

Dentro do sistema de substituição de importações, intensificado no período militar, havia ampla regulação do mercado, em particular do comércio exterior. A produção nacional era protegida por tarifas alfandegárias e autorizações prévias de importação, o que tornava o mercado interno pouco exposto à concorrência externa. Por essa regulação do comércio exterior e administração dos instrumentos relacionados com a agricultura, inclusive um amplo sistema de subsídios, o governo visava garantir simultaneamente a renda do produtor e a estabilidade dos preços ao consumidor. Mesmo os produtos destinados ao mercado externo eram controlados pelo governo, pela necessidade de excedentes exportáveis. Além do controle da administração da taxa cambial e do crédito subsidiado, foram mantidos ou reforçados regulamentos para orientar as exportações. O governo também criou programas para o desenvolvimento regional, em particular para o cerrado, cuja exploração econômica era inviável com a tecnologia disponível.

O governo também investiu pesadamente em pesquisa agrícola moderna. Em 1973, criou a Empresa Brasileira de Pesquisa Agropecuária (EMBRAPA), responsável por um maciço programa de pesquisas destinado a prover tecnologia moderna à agricultura brasileira. Com foco no agronegócio, e contando com centenas de pesquisadores formados no Brasil e em grandes centros universitários internacionais, a EMBRAPA visava fornecer soluções para o desenvolvimento da agricultura tropical, 
inclusive uma nova geração de plantas e sementes adaptadas às condições locais. O sofisticado trabalho de pesquisa da EMBRAPA e de outros centros de pesquisa no Brasil explica a grande parte dos ganhos de produtividade agrícola obtidos nos últimos 20 anos no Brasil e a ocupação econômica do Cerrado (Alves, 2013; Alves; Souza, 2007) - ver Tabela 1.

Tabela 1 - Área plantada, produção e produtividade dos principais cultivos $(1976 / 77-2017 / 18)$

\begin{tabular}{|c|c|c|c|c|c|c|}
\hline & \multicolumn{2}{|c|}{ ÁreA (ha) } & \multicolumn{2}{|c|}{ Produção $(1.000 \mathrm{t})$} & \multicolumn{2}{|c|}{ Produtividade/ha } \\
\hline Produto & $1976 / 77$ & $\begin{array}{l}\text { 2017/18 } \\
\text { estimada }\end{array}$ & $1976 / 77$ & $\begin{array}{l}\text { 2017/18 } \\
\text { estimada }\end{array}$ & $1976 / 77$ & $\begin{array}{l}\text { 2017/18 } \\
\text { estimada }\end{array}$ \\
\hline Algodão & 4.096 & 1.143 & 1.176 & 2.780 & 287 & 2.432 \\
\hline Amendoim & 222 & 145 & 314 & 500 & 1.413 & 3.438 \\
\hline Arroz & 5.992 & 1.944 & 8.993 & 11.279 & 1.501 & 5.802 \\
\hline Aveia & 40 & 340 & 37 & 752 & 940 & 2.210 \\
\hline Cevada & 94 & 108 & 95 & 323 & 1.018 & 2.984 \\
\hline Feijão & 4.539 & 3.194 & 2.215 & 3.300 & 488 & 1.033 \\
\hline Milho - total & 11.797 & 16.382 & 19.256 & 87.279 & 1.632 & 5.328 \\
\hline Milho - primeira safra & 11.797 & 4.993 & 19.256 & 25.121 & 1.632 & 5.032 \\
\hline Milho - segunda safra & - & 11.389 & - & 62.158 & - & 5.458 \\
\hline Soja & 6.949 & 35.047 & 12.145 & 113.025 & 1.748 & 3.225 \\
\hline Sorgo & 178 & 653 & 435 & 1.879 & 2.450 & 2.879 \\
\hline Trigo & 3.153 & 1.916 & 2.066 & 4.657 & 655 & 2.431 \\
\hline
\end{tabular}

Fonte: $\mathrm{CONAB},<$ http://www.conab.gov.br/conteudos.php?a=1252>.

A soja destaca-se entre os novos grãos que fizeram parte da modernização agrícola do Brasil. Introduzida no final da década de 1950, alcançou a produção de 15 milhões de toneladas em 1980, patamar apenas superado pelo milho. A produção de suco de laranja apresentou também rápido crescimento, tornando-se um dos principais itens na pauta de exportações. A cana-de-açúcar também logrou grande expansão, especialmente após a implantação do PROÁLCOOL em 1975. Mesmo a cultura do trigo apresentou crescimento excepcional através de fortes incentivos governamentais oferecidos aos produtores e consumidores. No entanto, outros produtos alimentares não apresentaram bom desempenho nesse período inicial. O milho que se tornaria uma das culturas com melhor desem- 
penho no século XXI, apresentou reduzido aumento na produtividade nessa primeira fase. $\mathrm{O}$ mesmo ocorreu com o arroz, o feijão e a mandioca, cujas produção e produtividade pouco cresceram. O resultado da agricultura até o final da era militar foi positivo, com um significativo aumento na produção, incrementos significativos na produtividade de inúmeros cultivos e a formação de complexo setor agroindustrial. Entre 1960 e 1980, a área cultivada quase dobrou, de 25 milhões para 47 milhões de hectares, acompanhada por uma crescente mecanização (MAPA, IBGE, IPEADATA).

Como todos os setores da economia, a agricultura foi afetada pela crise das décadas de 1980 e 1990. A necessidade de ajustes internos e externos levou à adoção de políticas recessivas reforçadas por acordos com o FMI. A oferta de crédito rural, baseada em grandes subsídios governamentais e no uso de recursos provenientes dos depósitos à vista, reduziu-se de forma dramática. Em 1984, o crédito para a agricultura representava apenas 37\% do valor do volume disponível em 1979; em 1990, caiu para 23\% (BCB-SICOR). Infelizmente, a sucessão de políticas recessivas e planos heterodoxos foi ineficaz para conter o processo inflacionário, criando grande incerteza e prejudicando a agricultura com seus longos ciclos produtivos.

Mas a crise, que afetou todos os setores da economia, proporcionou oportunidades para a agricultura. A crise internacional do petróleo e suas consequências para as contas externas, que culminariam na moratória de 1987, deram à agricultura um novo papel na medida em que o governo promoveu a substituição do petróleo pelo etanol. Além disso, diante dos gargalos externos, o governo intensificou os estímulos às exportações agrícolas. Políticas diferenciadas foram estabelecidas para os produtos destinados ao mercado externo, como café, açúcar, soja, suco de laranja, cacau, algodão e tabaco.

Quanto aos produtos destinados ao mercado interno, a preocupação era o impacto na inflação. Mantinha-se um amplo sistema de subsídios reduzidos ou eliminados pela necessidade de controlar os gastos públicos. O trigo foi o caso mais emblemático. Cotas de produção, controle externo e subsídios ao produtor e ao consumidor tornavam o produto rentável ao produtor, que aumentava a oferta, e reduzia o preço ao consumidor, que ampliava a demanda. Sua importância na dieta básica e o potencial impacto político da adoção dos preços reais adiaram a eliminação dos 
subsídios. Mas em 1987 eles foram eliminados; em 1990 o mercado livre foi estabelecido para todas as etapas da produção e comercialização (Cole, 1998; Fernandes Filho, 1995).

Com a crise do petróleo implantou-se o PROÁLCOOL, ambicioso programa de produção e consumo de álcool como combustível automotivo. Lançado em 1975, o programa expandiu-se em 1979, após o segundo choque do petróleo. Além de adicionar álcool à gasolina, o governo incentivou a fabricação de carros movidos exclusivamente com álcool hidratado. Para promover o programa, vários incentivos fiscais foram disponibilizados, juntamente com financiamentos públicos. O governo administrou uma política que remunerava eficientemente o produtor de álcool e tornava esse combustível competitivo. Embora muito oneroso em termos de recursos públicos, o PROÁLCOOL mostrou-se eficaz e o mercado orientou-se quase exclusivamente para veículos movidos a álcool. Entretanto, com o declínio dos preços do petróleo, o álcool tornou-se pouco competitivo. Assim, em meados da década de 1980, o programa entrou em crise, com retração das vendas de veículos movidos a álcool na década de 1990. A atual tendência de alta nos preços do petróleo e a retomada do suporte público revitalizaram o programa no início do século XXI, reforçado pelo surgimento dos motores flex. Hoje, o Brasil é o segundo maior produtor de etanol do mundo e o álcool combustível respondeu por $66 \%$ do consumo de gasolina do país (ANP, 2018, p. 145, 178).

No final da década de 1980 e ao longo da década de 1990, a maior parte do mundo estava sendo arrastada por uma onda neoliberal, que se refletiu por fim no Brasil. A Rodada Uruguai do Gatt, que resultou na criação da Organização Mundial do Comércio (OMC), ao ser concluída em 1993, incluiu um importante acordo sobre a agricultura, concentrado em três pontos principais: acesso a mercados, subsídios às exportações e apoio doméstico à agricultura. Definiu também a necessidade de reduzir as tarifas sobre os alimentos importados. Esse acordo contribuiu de forma efetiva para a liberação do comércio e a entrada de grandes grupos multinacionais em países subdesenvolvidos (Albano, 2001, p. 126-151). Em 1991, através do Tratado de Assunção, foi criado o MERCOSUL, zona regional de livre mercado, que permitia a livre circulação de bens, serviços e fatores produtivos entre as nações signatárias (Bastos, 2008; Carvalho; Silva, 2009). 
A abertura do mercado agrícola das décadas de 1980 e 1990 refletia a tendência mundial para liberar o comércio. A abertura seria reforçada pela política de liberalização ampla adotada no governo de Fernando Collor. Além do processo de abertura, o setor agrícola sofreu também os impactos da redução drástica dos subsídios, que oneravam sobremaneira o orçamento público. O subsídio total, que somou US \$ 5,3 bilhões em 1987, dois anos depois era de apenas US\$ 1 bilhão (Silva, 1996).

A abertura do mercado nacional ocorreu em etapas. Em 1988, adotou-se uma grande redução nas tarifas, reforçada em 1990, quando se eliminaram todas as restrições às importações de produtos agrícolas. No ano seguinte, foi estabelecido um cronograma para o processo de reduções e simplificações tarifárias. A tarifa média caiu de $32 \%$ para $14 \%$; e a taxa máxima, de $105 \%$ para $35 \%$. Ao final do processo, a maioria dos produtos passou a ser taxada em apenas $10 \%$. De modo geral, a abertura ampla da economia foi benéfica para a agricultura, pois, exceto o trigo, a produção local tonou-se competitiva, porque a abertura permitiu a aquisição de insumos e máquinas agrícolas a preços do mercado internacional (Fonseca, 2007). Entre 1991 e 1992, as licenças prévias de importação e exportação de produtos agrícolas também foram eliminadas, bem como os impostos cobrados sobre as exportações de diversos produtos agrícolas. Até mesmo o segmento de açúcar e álcool, regulado por um complexo sistema de cotas, passou a atuar no mercado livre.

Mesmo nas turbulentas décadas de 1980 e 1990, a agricultura registrava um crescimento médio anual de 3\%, superior ao crescimento médio do PIB no período. No entanto, o desempenho era errático, alternando anos positivos e negativos, e exibindo melhores resultados na produção para a exportação do que na produção destinada ao mercado interno. Se considerarmos a crise enfrentada pela agricultura nesse período, com a aceleração inflacionária, as políticas recessivas, a crise fiscal, a eliminação dos subsídios e a redução da oferta de crédito oficial, podemos considerar positivo o desempenho da agricultura. $\mathrm{O}$ colapso do apoio do governo na década de 1980 e a abertura da economia nacional ao comércio mundial na década de 1990 forçaram uma reorganização profunda da economia brasileira. A indústria e a agricultura contavam com apoio amplo do governo nas décadas anteriores, mas apenas a agricultura foi capaz de realizar as transformações necessárias para competir com sucesso no mercado internacional, em face do espetacular 
crescimento da produtividade. Este é um resultado surpreendente e que tem inúmeras causas internas e externas, e fortemente influenciado por políticas governamentais. Desde a década de 1960, o apoio do governo permitiu que a agricultura mantivesse uma importância fundamental na geração de exportações e, ao mesmo tempo, fornecesse aos mercados locais, de maneira eficiente e barata, matérias-primas. O aumento extraordinário da demanda urbana proporcionou um mercado importante e em expansão que permitia o crescimento contínuo da agricultura.

Lembremos que nesse período não só ocorria crescimento acelerado da população brasileira, como o país se tornou cada vez mais urbano, passando de 45\% em 1960 para 75\% urbano em 1990 e para 84\% em 2010 (IBGE-SIDRA, Tabela 1.288). O governo procurava controlar os preços dos produtos agrícolas, particularmente dos alimentos, administrando um amplo sistema de subsídios. Ao mesmo tempo, a agricultura consumia máquinas, equipamentos e matérias-primas produzidas internamente, proveniente de indústrias protegidas, de baixa produtividade, que vendiam seus produtos a preços elevados, muito acima dos praticados no mercado internacional. Essa estrutura de produção resultava do processo de substituição de importações, adotado no Brasil a partir da década de 1940 e intensificado no período militar.

Foi esse complexo sistema de subsídios que permitiu à agricultura aumentar sua produtividade através do uso de novos insumos industriais nacionais. $\mathrm{O}$ sistema funcionou adequadamente enquanto houve estabilidade econômica. Mas, com a crise fiscal do Estado e a inflação desenfreada a partir do final da década de 1980, o sistema de crédito abundante e subsidiado, público ou oferecido através das exigibilidades bancárias, entrou em colapso e precisou ser substituído por formas alternativas de crédito. Houve também a necessidade de integrar mais eficientemente as cadeias de produção do processo agroindustrial, reduzindo o papel controlador e provedor de recursos do governo. A produção agrícola integrou-se profundamente com os fornecedores privados de insumos agrícolas (como sementes, pesticidas e fertilizantes), processadores de produtos agrícolas (soja, suco de laranja, frigoríficos), distribuidores em geral (redes de supermercados) e empresas comerciais (trading companies).

Mas, quando a proteção generalizada que defendia a produção nacional deixou de existir, a própria agricultura enfrentou a concorrência internacional. A sobrevivência exigia o aumento da produtividade, que 
os agricultores mais empreendedores puderam obter através de novas tecnologias, sementes mais eficientes, aplicação mais sistemática de fertilizantes, inseticidas e intensificação no uso de máquinas e equipamentos. Grande parte dessa adaptabilidade resultou dos anos de pesquisas patrocinadas pelo governo, que forneceram aos agricultores brasileiros sementes e tecnologia adaptadas às condições do país, de suas várias regiões e seus múltiplos produtos, que permitiram transformar regiões inteiras do Brasil em centros produtivos de produção agrícola moderna. Esse foi o elemento dinâmico que explica a revolução na agricultura brasileira, que ocorria mesmo durante a prolongada crise da economia brasileira.

A transformação da economia brasileira desde a década de 1990 também foi muito influenciada pelo sucesso do Plano Real, que controlou o processo inflacionário.Após quase meio século de instabilidade econômica, aceleração da inflação e sucessivos planos de estabilização, o Plano Real, implantado em 1994, criou um novo padrão de relações econômicas, compatível com um país da importância econômica do Brasil. Além disso, a intensificação do processo de abertura, a maior exposição à concorrência internacional e a manutenção de uma moeda sobrevalorizada tiveram um efeito positivo na estabilidade de preços. Bens importados ou commodities brasileiras tiveram seus preços controlados pela concorrência, o que ajudou na fase inicial do Plano Real.Ao contrário da agricultura, completamente exposta à concorrência internacional, importantes setores industriais mantinham ainda níveis elevados de proteção, limitando o efeito progressivo sobre a produtividade industrial. A ideia era expor o Brasil à competição internacional para ter um impacto modernizador na economia, especialmente na indústria nacional.

Com a drástica redução dos recursos públicos para o setor agrícola, na forma de crédito e subsídios, havia necessidade de obter novas fontes de crédito rural suportáveis pela agricultura. Esses mecanismos alternativos de crédito começaram a ser adotado no início da década de 1990, quando houve um aumento no fluxo de recursos internacionais privados para a agricultura. O setor agrícola beneficiava-se da abertura financeira, que proporcionava também acesso a crédito mais barato no mercado internacional. Essa modalidade de crédito beneficiava essencialmente os produtores de commodities, menos vulneráveis ao risco das operações financeiras denominadas em dólares (Helfand; Rezende, 2001, p. 4-5). O governo também criou mecanismos públicos e privados para aumentar 
a oferta de crédito agrícola, mesmo quando se esgotaram os programas anteriores. Assim, em 1986, quando a Conta de Movimento (que supria recursos monetários à agricultura) foi encerrada, criou-se a Caderneta de Poupança Rural, cujos recursos seriam aplicados exclusivamente à agricultura. Abriu-se uma alternativa nova de captação de recursos para a agricultura, utilizando-se um instrumento financeiro conhecido, facilitando sua aceitação. Em 1987 a caderneta já representava mais de um quinto dos recursos destinados à agricultura e desde então se constitui em uma importante fonte de recursos para o setor.

O governo também tentou proteger os produtores contra as flutuações dos preços relativos. Em 1991, a Lei n. 8.174, a chamada Lei Agrícola, criou o mecanismo de pagamento das operações de crédito por equivalência em produto. Como os contratos de crédito agrícola eram corrigidos pela inflação, a correção dos preços de garantia de compra do governo federal pelo mesmo índice de correção aplicado ao respectivo empréstimo eliminava o risco da disparidade de indicadores, que aumentava quando a inflação atingia níveis excepcionais (Araújo, 2001, p. 29-30). No mesmo ano, o Banco Nacional de Desenvolvimento Econômico e Social (BNDES) intensificou sua atuação na área agrícola, utilizando diversas linhas de financiamento tradicionalmente voltadas ao setor industrial. O banco concentrou-se no financiamento dos investimentos rurais. Em 1994 foi criado o Certificado de Produtor Rural (CPR), instrumento representativo da promessa de entrega futura de produtos agrícolas e que poderia ser emitido em dólares (Ruiz, 2015). O CPR representou um instrumento importante para a integração da agricultura brasileira com o mercado internacional, uma vez que permitiu a venda direta e antecipada da produção. Em 2001, a lei foi complementada permitindo a liquidação financeira do certificado, completando a lei original que exigia a liquidação em produtos. Em 1998, uma resolução criou a chamada "63 Caipira", que representa repasses de empréstimos externos, realizados internamente em reais, mas com indexação em moeda estrangeira. Essa modalidade de empréstimo, tradicional no mercado financeiro brasileiro, constituiu mais um passo para a internacionalização das atividades do agronegócio no Brasil.

Em 1996, através do Programa de Fortalecimento da Agricultura Familiar (PRONAF), o governo criou um programa de longo prazo para apoiar os pequenos produtores. Visava ao desenvolvimento sustentável 
do segmento rural de agricultores familiares pelo aumento da sua capacidade produtiva, pela geração de empregos e pela melhoraria da renda produtiva. No mesmo ano, o governo autorizou a utilização de recursos do Fundo de Amparo ao Trabalhador (FAT) para financiar pequenos e médios produtores através do PRONAF. Essas medidas de apoio aos pequenos produtores atenderam aos movimentos sociais e políticos, movimentos que ainda lutam pela reforma agrária, particularmente o Movimento dos Trabalhadores Rurais Sem Terra (MST).

Nos anos seguintes novos instrumentos financeiros para o setor agrícola foram criados, dando-lhe flexibilidade semelhante aos demais setores econômicos e expandindo opções de crédito, financiamento da aquisição de insumos e de comercialização. São novos instrumentos que consolidaram variadas formas de financiamento aos investimentos, à produção e à comercialização agrícola, necessários para a nova etapa da agricultura brasileira, que se tornava mais complexa e passava a operar através de amplas cadeias de valor, envolvendo várias etapas do processo produtivo, com a participação de agentes no Brasil e no exterior. Este é um setor absolutamente integrado ao mercado internacional, dispondo de tecnologia e instrumentos de comercialização e financiamento comparáveis aos disponíveis pelos seus fortes concorrentes.

Embora menos dependente do setor público, particularmente de subsídios, a agricultura ainda depende em grande medida de fontes oficiais de financiamento ou crédito direcionado pelo setor bancário privado. Embora essas fontes de recursos cobrem taxas de juros abaixo das taxas do mercado livre de crédito, sempre representam taxas de juros reais positivas (Bacha; Danelon; Bel Filho, 2006, p. 43-69). Na safra 2013-2104, do montante de crédito disponibilizado, a chamada agricultura empresarial ou comercial absorveu $88 \%$ do crédito concedido e a agricultura familiar (PRONAF), 12\%. Do crédito disponibilizado, 73\% eram direcionados para o financiamento da produção e comercialização, e 27\%, para investimentos. No segmento de crédito para a agricultura comercial, $60 \%$ foram realizados com taxas de juros controladas e o restando ocorreu no segmento de taxas livres. As principais fontes de recursos foram Recursos Obrigatórios derivados dos depósitos à vista (27\%), Poupança Rural (14\%), BNDES (14\%), Banco do Brasil Agroindustrial (8\%). Dos recursos para investimentos, cerca de dois terços vieram dos programas administrados pelo BNDES. 
Desde a década de 1980, vêm surgindo novos mecanismos de financiamento criados para a agricultura por fornecedores e distribuidores de insumos, como empresas que vendem sementes, fertilizantes ou pesticidas; de empresas comerciais nacionais e internacionais; de processadores das agroindústrias; e de exportadores. O sistema funciona de várias maneiras, como os adiantamentos de recursos para a compra antecipada da safra por fornecedores e distribuidores de insumos, cujo crédito é pago após a respectiva colheita. Existem também operações de permutas, que envolvem a entrega fisica do produto, como forma de pagamento dos insumos adquiridos a uma paridade pré-definida. De acordo com um estudo recente, a participação do crédito bancário é maior no Sul do país, enquanto há maior uso de crédito de fornecedores de insumos e empresas comerciais no financiamento da produção no Centro-Oeste (Silva, 2012a, p. 61-66).

O declínio do modelo de financiamento do governo estimulou a integração das cadeias de valor do agronegócio. O fazendeiro tornou-se um empreendedor para sobreviver e crescer no novo ambiente de negócios, em que o produtor pode comprar e vender seus insumos e produtos no mercado livre, aberto e global, mas também precisa competir nesse sofisticado mercado. É o mercado internacional que agora fixa os preços agrícolas, o que gera a dinâmica da produção, sua viabilidade e rentabilidade. Se há vantagens, também há riscos e se constitui em um ambiente absolutamente profissional (Buainain et al., 2014b, p. 1.176).

A introdução de fertilizantes e equipamentos agrícolas seria de grande importância no processo de modernização da agricultura brasileira, mas o setor não teria alcançado sua atual competitividade no mercado mundial de agronegócios sem grandes transformações tecnológicas e a difusão desse conhecimento pela agricultura brasileira. Nesse sentido, a EMBRAPA e outros institutos de pesquisa públicos e privados, bem como as empresas agrícolas multinacionais, desempenharam importante papel. No passado o crédito agrícola governamental estava associado à assistência técnica pública e privada.A ideia era fortalecer o capital humano para melhor utilizar os investimentos disponibilizados para a aquisição de bens de capital e insumos modernos. A assistência técnica estava vinculada ao crédito rural e era obrigatória até a década de 1990. Nos anos 2000, essa associação era obrigatória apenas para algumas linhas de crédito e, desde então, os agricultores mais integrados às cadeias de valor e ao mercado 
internacional têm usado predominantemente assistência técnica privada (Martha Jr.; Contini; Alves, 2012, p. 2.004-2.226; Peixoto, 2008, p. 26).

No início dos anos 2000, o governo voltou a envolver-se em ações de assistência técnica. Mas o sistema público de assistência técnica e extensão rural no Brasil agora se concentra no pequeno produtor, tendência que ocorreu em outros países. Os produtores comerciais devem obter tais serviços no mercado privado. Diversos estudos, patrocinados pela FAO e pelo Banco Mundial, apontaram que a modernização tecnológica da agricultura, a especialização dos produtores e a ampliação da escala de produção favoreceram o surgimento de um mercado privado de informação agrícola. O mesmo ocorreu no Brasil, com a consolidação de um amplo e sofisticado mercado de informação especializada, oferecida por entidades privadas, que incluem empresas de assistência técnica, fornecedores agrícolas e fabricantes de equipamentos.

Os produtores sem escala, mas que atuam na agricultura comercial, dos quais é exigida também elevada produtividade, podem beneficiar-se da integração vertical de cooperativas de produtores, empresas comerciais ou processadores industriais que fornecem conhecimento técnico, assim como crédito através de contratos a termo. De fato, tanto grandes quanto pequenos produtores têm respondido ativamente às crises das décadas de 1980 e 1990 com complexos arranjos privados, comerciais e cooperativos. Surgiu um segmento extraordinariamente empreendedor de agricultores que passaram a dominar a agricultura nacional, integrados a importantes cadeias de valor. Esses mecanismos permitem que os produtores reduzam coletivamente seus custos, compensem a falta de programas oficiais de extensão agrícola e utilizem rapidamente a tecnologia mais recente e mais adequada aos seus cultivos ou à sua criação. A evolução na integração produtiva alcançou também o sistema cooperativo. Muitas cooperativas e seus cooperados integraram-se solidamente nas principais cadeias de valor, difundindo e utilizando a mais moderna tecnologia agrícola e agroindustrial, e desenvolvendo complexos sistemas de financiamento e comercialização (Chaddad, 2016, p. 14-15).

Embora, nos últimos anos, as entidades governamentais federais e estaduais tenham intensificado sua atuação na extensão rural, a oferta de tais serviços não supre a necessidade de grande parte dos estabelecimentos de agricultores familiares identificados no Censo Agropecuário de 2006. Em contraste, no setor comercial moderno, os arranjos produ- 
tivos com fabricantes de máquinas e equipamentos, os fornecedores de insumos como sementes e fertilizantes e as firmas privadas de consultoria parecem suprir eficientemente as necessidades desses produtores, como evidenciado pelo uso generalizado de tecnologias e insumos modernos no Brasil, incluindo as chamadas culturas geneticamente modificadas.

Um fator fundamental que influenciou o crescimento da agricultura neste início de século foi a melhoria maciça na produtividade em quase todas as culturas, resultado influenciado pela pesquisa agrícola nacional. Até a década de 1950, havia limitada pesquisa agrícola pública ou privada e baixa coordenação entre os poucos centros existentes no país. Existiam alguns centros de pesquisa e extensão, estatais e privados, fundados no século XIX e início do século XX.Vários pertenciam a escolas agrícolas fundadas no Brasil naquela época, que posteriormente se integraram em grandes universidades, e contando no final do século XX com modernas instalações de ensino e pesquisa. Naquela fase inicial coexistiam importantes centros estaduais e federais de pesquisa agrícola. Entre os mais importantes, podemos destacar o Instituto Agronômico de Campinas, a Escola Superior de Agronomia Luiz de Queiroz (ESALQ), a Escola de Agricultura de Lavras e a Escola de Veterinária deViçosa. Mas, sem uma infraestrutura nacional, a difusão dos resultados das pesquisas era ainda limitada.

A criação da Empresa Brasileira de Pesquisa Agropecuária (EMBRAPA), além de intensificar a pesquisa agrícola em geral, viria a suprir a lacuna da difusão nacional e regional dos resultados. Na sua origem a EMBRAPA enfatizou a necessidade de adaptar as tecnologias estrangeiras às condições brasileiras. As pesquisas deveriam estar diretamente relacionadas a programas bem definidos por produto ou por região, com avaliação permanente dos resultados. Talvez o fator mais importante para explicar o sucesso da EMBRAPA tenha sido sua política de recursos humanos e seu programa de treinamento. Esse programa de treinamento permitiu que o Brasil expandisse a oferta de pesquisadores com uma visão global do desenvolvimento brasileiro, para que pudessem selecionar seus projetos de pesquisa dentro desse modelo. A EMBRAPA rapidamente contratou e capacitou centenas de pesquisadores em instituições de ensino no Brasil e no exterior, principalmente nos Estados Unidos, contando com recursos próprios e apoio financeiro de inúmeras entidades 
nacionais e internacionais, como FINEP, BIRD, BID e USAID (Mengel, 2015, p. 127-140; Cabral, 2015, p. 142). Em 2016, a EMBRAPA empregava 2.444 pesquisadores, sendo 330 mestres, 1.829 doutores e outros 285 com pós-doutorado. Apesar de algumas flutuações, houve um aumento constante nas alocações orçamentárias para a EMBRAPA pelo governo federal (EMBRAPA, 2016, p. 32).

Embora o crédito governamental e outras políticas públicas tenham sido importantes na fase inicial da modernização, sem a qual não haveria agronegócio no Brasil, é a produtividade que explica a contínua competitividade da agricultura brasileira, apesar das dificuldades estruturais enfrentadas em todas as áreas. $\mathrm{O}$ mercado internacional foi essencial nesse processo, pois permitiu o aumento contínuo da produtividade, porque era praticamente ilimitado para um produtor competitivo. Um processo de aumento contínuo da competitividade teria sido impossível em um mercado local fechado, por maior que fosse. A expansão da oferta teria causado uma queda nos preços agrícolas, impedindo aumentos sequenciais na produção por meio de maior produtividade (Paiva; Schattan; Freitas, 1973, p. 17-27).

Impressiona a magnitude dos avanços do agronegócio no Brasil. A área plantada cresceu de 40 milhões de hectares na década de 1980 para 62 milhões de hectares na safra 2017-2018. Em contraste com esse aumento relativamente modesto na área plantada, houve um crescimento maciço na produção, que passou de aproximadamente 50 milhões de toneladas de grãos para 230 milhões de toneladas no mesmo período. Esse crescimento excepcional de produção resultou do aumento extraordinário da produtividade, que passou de $1.400 \mathrm{~kg}$ por hectare na década de 1980 para cerca de $3.500 \mathrm{~kg}$ por hectare nas primeiras oito safras da década de 2010 (ver Gráfico 1).

Em razão desse desempenho, os rendimentos produtivos atuais das principais culturas comerciais no Brasil assemelham-se aos obtidos nos países mais avançados. Assim, em 2014, o rendimento médio de soja por hectare no Brasil superou o rendimento da soja na Argentina e representa $90 \%$ do rendimento obtido nos Estados Unidos. Quanto ao milho, o rendimento obtido em Goiás representa $77 \%$ do rendimento americano e $89 \%$ do rendimento canadense (FAOSTAT e CONAB).

Embora os indicadores de produção por área sejam uma forma prática de medir e comparar a produtividade agrícola, a melhor maneira é 


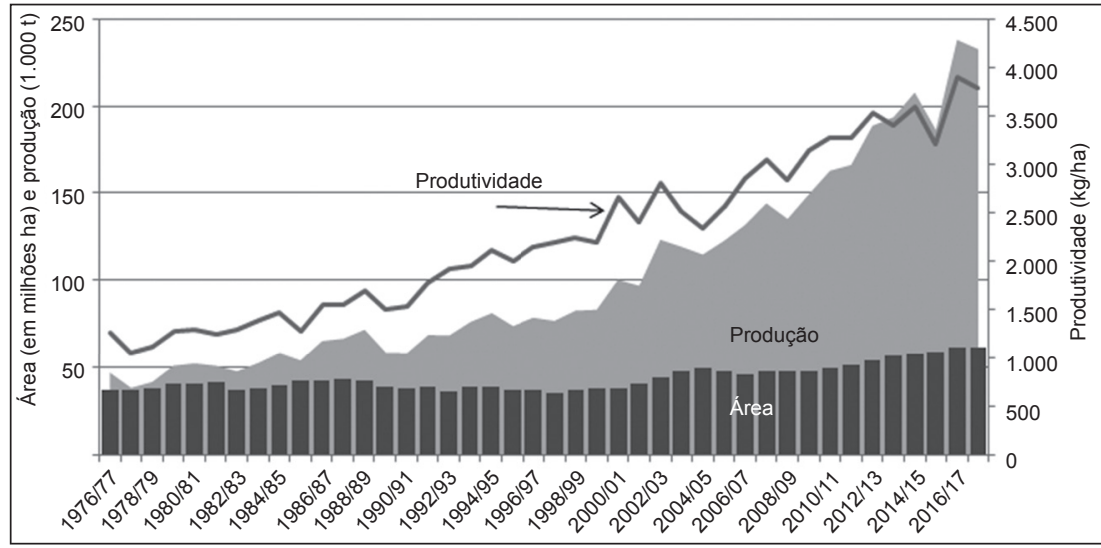

Fonte: CONAB, Série Histórica (Safra 2017-2018 - estimativa), <https://www.conab.gov.br/info-agro/ safras/serie-historica-das-safras>.

analisar a dinâmica da Produtividade Total dos Fatores (ou PTF), que mede a relação entre a produção e a quantidade de insumos utilizados, como terra, trabalho e capital.Vários estudos demonstram que o Brasil teve um desempenho extraordinário na PTF comparável aos países com o melhor desempenho agrícola (Gasques et al., 2010, 2012). Um dos estudos, relativo ao período 1975 a 2011, mostra um crescimento excepcional da produtividade do trabalho, da ordem de 4,29\% ao ano, seguido pela produtividade da terra $(3,77 \%$ ao ano). Parte desse crescimento deu-se pela incorporação de terras novas, altamente produtivas, e pela adoção de novas práticas de cultivo, mas o maior efeito resultou dos investimentos em pesquisa, serviços de extensão e uso de novas tecnologias. Nesse período (1975 a 2011), a PTF cresceu 3,56\% ao ano, o que representa um resultado excepcional quando considerado um período de tempo tão longo. Além disso, a PTF aumentou nos últimos anos do estudo, atingindo a média anual de 5,6\% (Gasques et al., 2012). Ou seja, a produção continua crescendo em ritmo acelerado, embora a quantidade de insumos permaneça praticamente estável. A elevada e crescente produtividade agrícola torna o Brasil altamente competitivo no mercado agrícola internacional (ver Tabela 2).

A pesquisa básica é essencial para o crescimento da produtividade, especialmente em um país tropical, porque abre possibilidades em termos de descobertas de novas variedades, que são mais resistentes e produtivas; 
Tabela 2 - Fontes de crescimento da agricultura brasileira - taxas anuais de crescimento (1975-2011)

\begin{tabular}{l|c|c|c|c|c|c}
\hline \multicolumn{1}{c|}{ INDICADORES } & $1975-2011$ & $1975-1979$ & $1980-1989$ & $1990-1999$ & $2000-2009$ & $2000-2011$ \\
\hline Índice de produção & 3,77 & 4,37 & 3,38 & 3,01 & 5,18 & 4,85 \\
\hline Índice de insumos & 0,20 & 2,87 & 2,20 & 0,36 & $-0,51$ & $-0,80$ \\
\hline Fator total de produtividade & $\mathbf{3 , 5 6}$ & $\mathbf{1 , 4 6}$ & $\mathbf{1 , 1 6}$ & $\mathbf{2 , 6 4}$ & $\mathbf{5 , 7 2}$ & $\mathbf{5 , 6 9}$ \\
\hline Produtividade do trabalho & 4,29 & 4,25 & 2,13 & 3,52 & 5,86 & 5,71 \\
\hline Produtividade da terra & 3,77 & 3,15 & 2,91 & 3,25 & 5,61 & 5,32 \\
\hline Produtividade do capital & 3,05 & 2,77 & 2,87 & 1,89 & 4,62 & 4,35 \\
\hline
\end{tabular}

Fonte: Gasques et al. (2012, p. 89).

desenvolve técnicas de manejo aprimoradas e novas formas de plantio; promove a melhoria na qualidade dos insumos e lida com condições muitas vezes exclusivas dos trópicos. Os efeitos da pesquisa não são imediatos, mas cumulativos, e também variam ao longo do tempo, dependendo da cultura e dos solos. Juntamente com a pesquisa, os resultados da extensão rural e os serviços de orientação fornecidos por centros públicos e privados de pesquisa também são significativos. Nesse sentido, o papel da EMBRAPA e de outras entidades públicas e privadas foi crucial, pois proporcionou aos agricultores meios e conhecimentos para adotar mudanças tecnológicas e inovações adaptadas às condições específicas do clima e dos solos locais. De acordo com o estudo dos resultados da PTF, o efeito mais forte sobre a produtividade está relacionado aos gastos com pesquisa. Um aumento de $1 \%$ nos gastos com pesquisa resulta em um aumento de $0,35 \%$ na PTF, seguido em importância pelo crédito e pelas exportações (Gasques et al., 2012).

O desempenho do Brasil na PTF da agricultura mostra-se elevado se comparado aos principais países agrícolas do mundo. No período de 2001 a 2009, por exemplo, a PTF da agricultura brasileira apresentou crescimento anual médio de 4\%, contra 2,8\% na China, 2,3\% nos Estados Unidos e 2,1\% no Canadá e na Índia.A Argentina e a Austrália apresentaram taxas de crescimento significativamente menores. A China e a Índia não são concorrentes do Brasil e, de fato, são seus principais mercados. A competição brasileira é com outros grandes produtores e exportadores de carnes e grãos, como os Estados Unidos, a Austrália e o Canadá (Fuglie, 2012). O desempenho brasileiro foi excepcional desde a década de 1980 (ver Tabela 3). 
Tabela 3 - Valor de produção e Produtividade Total dos Fatores por países e grupo de países variação anual (1961-2009)

\begin{tabular}{|c|c|c|c|c|c|c|}
\hline \multirow{2}{*}{$\begin{array}{c}\text { PAÍSES E GRUPO } \\
\text { DE PAÍSES }\end{array}$} & \multirow{2}{*}{\begin{tabular}{|l|} 
VALOR DA \\
PRODUÇÃOO
\end{tabular}} & \multicolumn{5}{|c|}{ PTF AGRICULTURA - VARIAÇÃO ANUAL } \\
\hline & & $1961-1970$ & 1971-1980 & $1981-1990$ & $1991-2000$ & 2001-2009 \\
\hline $\begin{array}{l}\text { Todos os países em } \\
\text { desenvolvimento }\end{array}$ & & 0,7 & 0,9 & 1,1 & 2,2 & 2,2 \\
\hline $\begin{array}{l}\text { Todos os países } \\
\text { desenvolvidos }\end{array}$ & & 1,0 & 1,6 & 1,4 & 2,2 & 2,4 \\
\hline $\begin{array}{l}\text { Economias em } \\
\text { transição }\end{array}$ & & 0,6 & $-0,1$ & 0,6 & 0,8 & 2,3 \\
\hline Brasil & 127 & 0,2 & 0,5 & 3,0 & 2,6 & 4,0 \\
\hline Estados Unidos & 229 & 1,2 & 1,8 & 1,2 & 2,2 & 2,3 \\
\hline China & 487 & 0,9 & 0,6 & 1,7 & 4,2 & 2,8 \\
\hline Argentina & 41 & 0,2 & 3,1 & $-1,0$ & 1,5 & 1,2 \\
\hline Austrália & 23 & 0,6 & 1,7 & 1,3 & 2,9 & 0,6 \\
\hline Índia & 205 & 0,5 & 1,0 & 1,3 & 1,2 & 2,1 \\
\hline Canadá & 28 & 1,4 & $-0,4$ & 2,7 & 2,6 & 2,1 \\
\hline
\end{tabular}

Fonte: Fuglie (2012).

Nota:Valor da produção - média período 2006-2009.US\$ - valores constantes de 2005.

Esse desempenho extraordinário da agricultura brasileira ocorreu quando a economia brasileira como um todo não teve bons resultados. A produtividade geral no Brasil é baixa mesmo em comparação com países semelhantes, e estagnou desde a década de 1980. O desempenho excepcional da agricultura brasileira em termos de produção e produtividade permitiu que o Brasil desempenhasse um papel importante no mercado internacional de produtos do agronegócio. Embora o setor agrícola tenha uma participação reduzida na composição do PIB nacional, da ordem de 5\%, o chamado agronegócio, que inclui a produção agrícola propriamente dita, a transformação industrial dos produtos agrícolas, os canais de distribuição da produção, a cadeia de fornecimento de insumos para a agricultura, inclusive máquinas e equipamentos, a logística, a pesquisa, a assistência técnica e os serviços financeiros relacionados com a agricultura representam atualmente mais de $20 \%$ do PIB nacional. Esse segmento produtivo tem um grande impacto na economia brasileira, no valor da produção, nos empregos e principalmente nas exportações (CEPEA-ESALQ).

O comportamento do agronegócio representa fator fundamental para o equilíbrio da balança de pagamentos. As exportações do agrone- 
gócio cresceram constantemente desde o início do século XXI. Partindo de US $\$ 20$ bilhões em 2000, essas exportações alcançaram US\$ 100 bilhões em 2013, reduzindo-se para US $\$ 85$ bilhões nos anos 2015 e 2016. A maior importância do desempenho do agronegócio na área externa não é apenas a quantidade exportada, mas sua representatividade no valor total exportado pelo Brasil (46\% em 2015). Devemos chamar a atenção pelo resultado líquido da balança comercial do agronegócio. Como o Brasil exporta um valor elevado de produtos do agronegócio e as importações desse segmento são relativamente reduzidas, o país apresenta o melhor resultado líquido nas exportações do agronegócio, superando inclusive os Estados Unidos. Como a balança comercial brasileira, excluído o agronegócio, é muito negativa, são a exportações agrícolas que permitem a geração de saldos positivos na balança comercial brasileira (ver Tabela 4).

Tabela 4 - Valor das exportações e importações - totais e do agronegócio, Brasil (1990-2016)

\begin{tabular}{c|c|c|c|c|c|c|c|c}
\hline & \multicolumn{2}{|c|}{ ExPORTACOES (US\$ BILHÕES) } & \multicolumn{2}{|c|}{ IMPORTAC̃ES (US\$ BILHÕES) } & \multicolumn{2}{c}{ SALDO (US\$ BILHÕES) } \\
\hline Anos & $\begin{array}{c}\text { Total } \\
\text { Brasil } \\
\text { (a) }\end{array}$ & $\begin{array}{c}\text { Agronegócio } \\
(\mathrm{b})\end{array}$ & $\begin{array}{c}\% \\
\mathrm{~b} / \mathrm{a}\end{array}$ & $\begin{array}{c}\text { Total } \\
\text { Brasil } \\
\text { (a) }\end{array}$ & $\begin{array}{c}\text { Agronegócio } \\
(\mathrm{b})\end{array}$ & $\begin{array}{c}\% \\
\mathrm{~b} / \mathrm{a}\end{array}$ & $\begin{array}{c}\text { Total } \\
\text { Brasil }\end{array}$ & Agronegócio \\
\hline 1990 & 31,4 & 13,0 & $41 \%$ & 20,7 & 3,2 & $15 \%$ & 10,8 & 9,8 \\
\hline 1995 & 46,5 & 20,9 & $45 \%$ & 50,0 & 8,6 & $17 \%$ & $-3,5$ & 12,3 \\
\hline 2000 & 55,1 & 20,6 & $37 \%$ & 55,9 & 5,8 & $10 \%$ & $-0,7$ & 14,8 \\
\hline 2005 & 118,6 & 43,6 & $37 \%$ & 73,6 & 5,1 & $7 \%$ & 45,0 & 38,5 \\
\hline 2010 & 201,9 & 76,4 & $38 \%$ & 181,6 & 13,4 & $7 \%$ & 20,3 & 63,1 \\
\hline 2015 & 191,1 & 88,2 & $46 \%$ & 171,5 & 13,1 & $8 \%$ & 19,7 & 75,2 \\
\hline 2016 & 185,2 & 84,9 & $46 \%$ & 137,5 & 13,6 & $10 \%$ & 47,7 & 71,3 \\
\hline
\end{tabular}

Fonte: Elaboração com base em DAC/SRI/MAPA - para 2015:AGROSTAT Brasil, com base nos dados da SECEX/MDIC; para 2016: AGROSTAT e MICES.

O excepcional desempenho da agricultura brasileira também se beneficiou de mudanças no mercado internacional de commodities, particularmente no mercado de commodities agrícolas. Após um longo período de relativa estabilidade, ocorrido nas décadas de 1980 e 1990, os preços das commodities agrícolas cresceram rapidamente no início do século XXI, influenciados pela expansão da economia chinesa e sua participação no mercado de commodities. O Índice de Preços dos Alimentos da FAO, 
com base $=100$ na média dos anos de 2002 a 2004, atingiu o pico de 230 em 2011, representando crescimento de 130\% em uma década (FAO). Houve uma queda significativa após o pico de 2011, mas o índice ainda se mantém historicamente elevado, situando-se em 169 em julho de 2018. Apesar desse declínio, as exportações brasileiras do agronegócio conseguiram manter-se relativamente estáveis até 2014, mostrando queda significativa em 2015 e 2016 e recuperação em 2017. A competividade do Brasil permitiu um crescimento sistemático da produção pela crescente participação no mercado internacional. Mas isso só foi possível graças ao extraordinário aumento da produtividade agrícola, que pode manter o Brasil competitivo no mercado internacional, especialmente no longo prazo, quando terá que enfrentar períodos naturais de flutuações de preços. A única maneira de manter a posição brasileira no mercado mundial, ocupando posições de liderança em muitos produtos, será pelo aumento sistemático da produtividade (Buainain et al., 2014a).

É importante enfatizar que a transformação do Brasil em um grande exportador de produtos agrícolas ocorreu simultaneamente com o crescimento da produção e produtividade das culturas alimentares tradicionais. Isso permitiu que a agricultura suprisse adequadamente o mercado interno, o que, por sua vez, levou a uma queda sistemática nos preços internos dos alimentos locais. De acordo com um estudo recente, entre fevereiro de 1976 e agosto de 2006, o valor de uma cesta básica de alimentos declinou significativamente, na proporção de 3,13\% ao ano. Os autores concluem que os maiores beneficiários teriam sido os consumidores mais pobres e que, sem essa queda nos preços dos alimentos, os programas de transferência de renda realizados pelos governos Cardoso e Lula teriam menor sucesso (Alves et al., 2013, p. 22).

$O$ relato de sucesso apresentado neste artigo conta parte da história recente da agricultura brasileira.A análise procurou explicar como e por que as transformações ocorridas na agricultura tradicional brasileira levaram a um setor agrícola moderno e competitivo no mercado internacional. No entanto, essa transformação ocorreu apenas em uma parte do mundo rural, pois a maioria das propriedades agrícolas adota métodos agrícolas tradicionais e uma grande parcela da população rural está em condições precárias. Assim, parte da agricultura brasileira, ao contrário de outros sistemas agrícolas comerciais modernos, ainda é composta por 
agricultores pobres, com baixo nível de escolaridade e dedicados à produção de subsistência.

É interessante observar que a concentração da propriedade da terra é uma característica histórica da agricultura brasileira.Apesar da modernização de setores significativos da economia rural, a distribuição da propriedade rural permaneceu inalterada desde os primeiros censos e pesquisas cadastrais. Até meados do século XX, os latifúndios improdutivos e as precárias relações trabalhistas prevaleciam e sustentavam uma estrutura de poder atrasada e conservadora. Os governos militares, embora estimulassem os proprietários de terras a usarem maquinário, fertilizantes e inseticidas e lhes dessem crédito abundante, não agiram contra a concentração da propriedade da terra nem contra o poder das elites rurais conservadoras, de cujo apoio dependiam.

Em 1964, ao mesmo tempo que combatia ferozmente os movimentos reivindicatórios na área rural (Bruno, 1997, p. 99), o regime militar aprovou o Estatuto da Terra, que representava um modelo de colonização, visando promover uma melhor distribuição da terra. Mantido o direito de propriedade, o processo de desapropriação deveria ser feito pelo justo pagamento do valor da terra. Foi uma maneira de reduzir a pressão dos movimentos em favor da reforma agrária e, ao mesmo tempo, favorecer o processo de modernização da agricultura sem alterar a estrutura agrária em vigor (Martins, 1985, p. 35; Bruno, 1995). Mas mesmo essa forma de colonização, moderada em face das pressões então existentes, sofreu forte oposição conservadora no Congresso e em partes do Exército (Salis, 2008). Com a lei, foi iniciado um processo que envolveu a desapropriação de terras privadas improdutivas e terras públicas disponíveis. Embora ocorressem mudanças nos últimos 50 anos, este seria o procedimento adotado inclusive pelos governos democráticos. Apesar da contínua discussão sobre a reforma agrária após a redemocratização, não houve mudança fundamental na política de colonização, apenas intensificação ou moderação no ritmo do processo.

Desde o início desse programa de colonização até 2013, foram realizados cerca de 9 mil projetos, envolvendo o assentamento de 1,1 milhão de famílias em cerca de 88 milhões de hectares (Rocha, 2013, p. 23). Esses assentados representavam 19\% das famílias de agricultores e cerca de um quarto da área total das propriedades no censo agropecuário de 2006. Entretanto, medida pelo Índice de Gini, a distribuição de terras 
permanece praticamente inalterada desde o primeiro censo agropecuário de 1920.

Entre 1920 e 1960, houve um significativo declínio no tamanho médio, mas desde então o tamanho permaneceu estável entre 60 e 70 hectares por estabelecimento.Apesar do número significativo de assentamentos, o número total de propriedades permanece estável desde 1970, em torno de 5 milhões. Isso indica que, ao mesmo tempo que ocorreram os assentamentos, houve uma redução proporcional de propriedades de pequeno e médio porte. Os números preliminares do censo agropecuário de 2017 mostram resultados similares tanto no número de propriedades, como no de área, de tamanho e do Índice de Gini, o que indica a continuidade da perversa estrutura da posse da terra (ver Tabela 5).

A disparidade entre os estabelecimentos evidencia-se pela relação entre o valor da produção e o do tamanho. Os produtores com até 100 hectares, que no censo de 2006 representavam 90\% dos estabelecimentos, obtiveram $41 \%$ do valor da produção; os $10 \%$ restantes, com estabelecimento acima de 100 hectares, participaram com 59\% do valor da produção. Esses pequenos e médios produtores produziram em média apenas $8 \%$ do valor da produção média dos estabelecimentos com área acima de 100 hectares. Naquele mesmo ano, metade das pessoas empregadas na agricultura estava em estabelecimentos com menos de 10 hectares; e, se considerarmos propriedades com menos de 100 hectares, esse percentual chegou a quase $90 \%$.

Como foi dito, em 1994, diante das fortes mobilizações rurais, inclusive dos pequenos produtores rurais que demandavam acesso ao crédito rural, o governo criou o Programa deValorização da Pequena Produção Rural (Bianchini, 2015). O programa definiu como pequeno produtor rural aquele que obtivesse ao menos $80 \%$ da sua renda bruta anual proveniente da agricultura, não empregasse trabalhadores permanentes e tivesse uma propriedade inferior a quatro módulos fiscais. Em 1996, essas políticas agrícolas pró-pequenos produtores foram intensificadas com a criação do Programa de Fortalecimento da Agricultura Familiar (PRONAF), com a finalidade de promover o desenvolvimento sustentável do segmento rural composto por agricultores familiares, de modo a capacitá-los a aumentar sua capacidade produtiva, gerar empregos e melhorar a sua renda. Para enquadramento, definiram-se um teto de renda bruta e a exigência de que ao menos a metade fosse obtida da exploração 


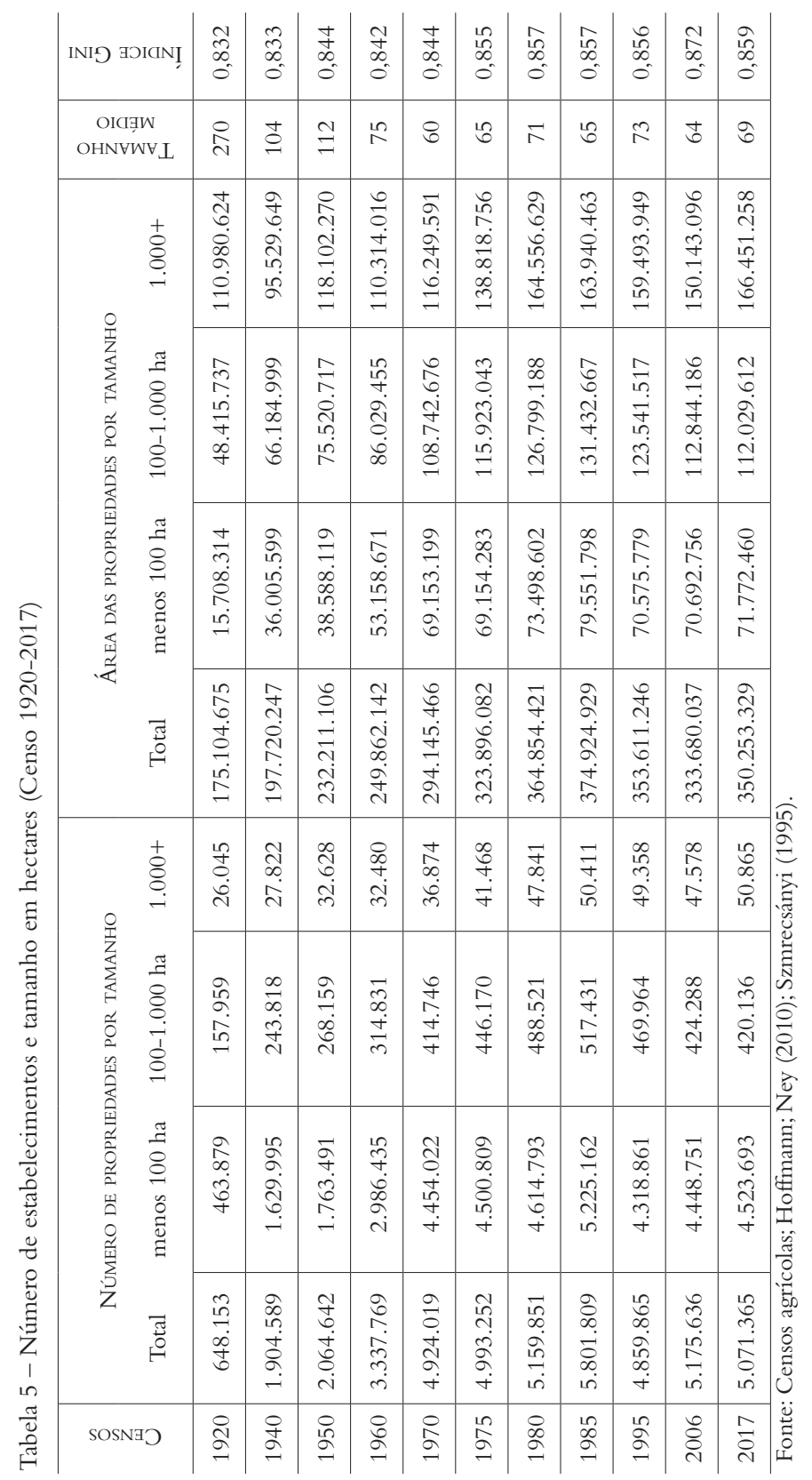


agropecuária ou não agropecuária do estabelecimento rural; o estabelecimento deveria utilizar mão de obra predominantemente familiar e não poderia ter área superior a quatro módulos fiscais. $\mathrm{O}$ fato de os programas governamentais serem direcionados a esse grupo de agricultores significa que eles passaram a representar um segmento diferenciado no mundo rural. Em 2006, utilizando esse novo conceito, foram recenseados cerca de 3,9 milhões de agricultores familiares e 736 mil agricultores não familiares (Guanziroli, 2001). Os agricultores familiares representaram $84 \%$ do total dos produtores rurais naquele censo, suas terras correspondiam a um quarto da área recenseada e a sua produção equivalia a um terço do valor total da produção agrícola. Em razão da sua grande representatividade numérica, os estabelecimentos da agricultura familiar continham três quartos dos empregados na área rural, embora a média de empregado por estabelecimento fosse de apenas 3,6, contra 6,0 das unidades não familiares. Dos 4,6 milhões de agricultores recenseados, apenas 919 mil receberam algum tipo de empréstimo, dos quais 736 mil eram agricultores familiares. Embora o PRONAF seja orientado para o crédito, apenas $20 \%$ dos agricultores familiares declararam a realização de alguma operação de crédito em 2006. Os números preliminares do censo agrícola de 2017 indicam situação similar.

Pequenos estabelecimentos familiares constituem a grande maioria das unidades e concentram parte significativa da mão de obra ocupada na agricultura, mas produzem apenas uma pequena parcela da produção. Porém esse tipo de análise agregada oculta informações importantes sobre os diferentes rendimentos por estabelecimento. Dependendo da estrutura da distribuição da renda, mesmo entre pequenos produtores ou produtores familiares, a média obtida a partir dos valores agregados pode distorcer os resultados. Uma análise interessante foi realizada por Alves, Souza e Rocha (2012). O estudo mostra que dois terços dos estabelecimentos acusaram renda bruta mensal de até 2 salários mínimos, mas essas unidades representavam apenas 3,3\% do valor bruto da produção em 2006. Na média estes 2,9 milhões de estabelecimentos obtinham em média 0,52 salários mínimos mensais como valor bruto da produção; por outro lado, apenas 27 mil estabelecimentos respondiam por mais da metade do valor bruto da produção, com produção média de 861 salários mínimos mensais. Em outro estudo,Alves e Rocha (2010, p. 276) segmentaram os estabelecimentos com valor bruto de produção de até 2 salários 
mínimos. São 3,7 milhões de unidades, onde residiriam cerca de $11 \mathrm{mi}-$ lhões de pessoas. Os resultados são dramáticos. Um conjunto de mais de 2 milhões de estabelecimentos, o que representa praticamente metade dos estabelecimentos recenseados, declararam renda bruta mensal inferior a meio salário mínimo. Estes tinham produção anual, que incluía o autoconsumo, de pouco mais de 2 salários mínimos. Considerando 3 pessoas por estabelecimento, essa renda anual representava $\mathrm{R} \$ 18$ mensais por pessoa, a ser comparada com o salário mínimo mensal de $\mathrm{R} \$ 300$ naquele ano. Como os autores consideram que tais resultados são explicados principalmente pelo padrão tecnológico adotado, não acreditam em solução futura a ser obtida diretamente pela agricultura. A renda deve ser complementada por programas distributivos, como Bolsa Família, Aposentadoria Rural, Bolsa Escola e outros. Embora os autores não acreditem que esse seja o processo mais conveniente, entendem que parte do problema será resolvida pela gradativa migração para as áreas urbanas e pela crescente parcela da população rural que obtém renda do trabalho fora do estabelecimento, em outras unidades agrícolas ou na área urbana.

Alguns autores sugerem um processo de desenvolvimento bifronte na área rural, coexistindo uma parte extremamente moderna, dinâmica, com altos índices de produtividade, e um amplo setor tradicional, que parece incapaz de avançar apesar das políticas públicas orientadas para seu fortalecimento, com instrumentos como o PRONAF (Navarro; Campos, 2014). Esse segmento do mundo rural enfrenta fortes desafios, como baixo nível de escolaridade dos produtores, incapacidade de utilizar as novas tecnologias, infraestrutura deficiente, tamanho e qualidade das terras, dificuldades de acesso aos mercados e ao crédito, embora este esteja disponível. Para esses autores, há um circulo vicioso de pobreza, que se perpetua. Embora os produtores rurais pobres sejam similares em termos de reduzida produção e baixa renda, esse grupo é heterogêneo em termos de potencial para aumentar a produtividade, a produção e a renda agrícola. Infelizmente, para uma grande parte desses agricultores pobres, o êxodo rural provavelmente será a solução.

Concluindo, a modernização da agricultura brasileira levou a uma profunda mudança na economia brasileira e à transformação do país em um dos maiores produtores e exportadores mundiais de produtos agropecuários. Contou inicialmente com o forte apoio governamental e 
acompanhou o processo de industrialização por substituição de importações. Em seguida, sobreviveu a numerosos choques de hiperinflação e ao fim da proteção tarifária nas décadas de 1980 e 1990. Isso ocorreu enquanto outros setores da economia estagnaram ou cresceram muito modestamente e com uma parcela significativa da população rural fora da agricultura comercial. Igualmente, ocorreu com uma população rural e força de trabalho agrícola em declínio. Infelizmente o sucesso do processo de modernização não alcançou todo o mundo rural, restando milhões de pequenos agricultores na pobreza, sem perspectivas de serem integrados à agricultura comercial moderna. Muitos somente poderão permanecer no campo contando com políticas de transferência de renda do governo federal. A manutenção e a ampliação da posição ocupada pelo Brasil no mercado internacional dependerão da capacidade de aumento contínuo da produtividade não somente pelo incremento da produtividade do segmento mais eficiente, mas, principalmente, pela gradativa melhoria da produtividade dos produtores menos eficientes, mas integrados à agricultura comercial, diretamente ou através de sistema cooperativos. Há no Brasil grande oferta de terras de alta qualidade, disponíveis para a agricultura, mas pouco produtivas, que poderão ser gradativamente incorporadas ao segmento comercial e altamente produtivo da agricultura brasileira. A postura do governo que assumiu em 2019 é um fato novo no cenário nacional. Muitas questões já superadas estão sendo questionadas, que no caso da agricultura envolve principalmente o meio ambiente. Essa nova postura, além das suas consequências internas na preservação do meio ambiente, deve trazer dificuldades futuras para a manutenção do papel do Brasil no agronegócio mundial. O mercado internacional exige sustentabilidade na produção, particularmente para um país que possui hoje alguns dos mais importantes biomas do mundo.

\section{Referências bibliográficas}

ALBANO, Gleydson P. Globalização da agricultura: multinacionais no campo brasileiro. Terra Livre. São Paulo, I, 36, p. 126-151, jan.-jun. 2001.

ALVES, Eliseu. Dilema da política agrícola brasileira: produtividade ou expansão da área agricultável. Brasília: EMBRAPA, 1983. 
ALVES, Eliseu et al. Fatos marcantes da agricultura brasileira. In:ALVES, Eliseu; SOUZA, Geraldo; GOMES, Eliane G. (orgs.). Contribuição da EMBRAPA para o desenvolvimento da agricultura no Brasil. Brasília: EMBRAPA, 2013, p. 13-46.

ALVES, Eliseu; ROCHA, Daniela de P. Ganhar tempo é possível?. In: GASQUES, J. G.; RIBEIRO FILHO, J. E.; NAVARRO, Zander (orgs.). A agricultura brasileira: desempenho, desafios e perspectiva. Brasília: IPEA, 2010, p. 275-289.

ALVES, Eliseu; SOUZA, Geraldo da Silva e. A pesquisa agrícola numa agricultura integrada ao mercado internacional. O caso da EMBRAPA e do Cerrado. Revista de Política Agrícola, v. 16, n. 2, p. 56-67, abr.-maio-jun. 2007.

ALVES, Eliseu; SOUZA, Geraldo da Silva e; ROCHA, Daniela de P. Lucratividade da agricultura. Revista de Política Agrícola, v. 21, n. 2, p. 45-63, abr.-maio-jun. 2012.

ANP. Anuário Estatístico Brasileiro do Petróleo, 2017. Rio de Janeiro: ANP, 2018.

ARAÚJO, Paulo F. C. de. Política de crédito rural: reflexões sobre a experiência brasileira. Brasília: CEPAL/IPEA, 2001.

BACHA, Carlos J. C. Economia e política agrícola no Brasil. São Paulo: Atlas, 2004.

BACHA, Carlos J. C.; DANELON, Leonardo; BEL FILHO, Egmar de. Evolução da taxa de juros real do crédito rural no Brasil - período 1985 a 2003. Teoria e Evidência Econômica. Passo Fundo, v. 14, n. 26, p. 43-69, maio 2006.

BASTOS, Luciana A. Avaliação do desempenho comercial do MERCOSUL:2004-2005. São Paulo: FFLCH-USP, 2008 (Tese de Doutorado).

BCB-SICOR. Banco Central do Brasil, Sistema de Operações do Crédito Rural. Disponível em <www.bcb.gov.br/?RELRURAL>. Acesso em 28/10/2018.

BIANCHINI, Valter. Vinte anos do PRONAF, 1995-2015. Avanços e desafios. Brasília: Ministério do Desenvolvimento Agrário, 2015.

BRUNO, Regina. O Estatuto da Terra: entre a conciliação e o confronto, 1995. Disponível em <http://r1.ufrrj.br/esa/V2/ojs/index.php/esa/article/viewFile/80/76>. Acesso em 18/3/2017.

BRUNO, Regina. Senhores da terra, senhores da guerra: a nova face política das elites agroindustriais no Brasil. Rio de Janeiro: Forense/UFRJ, 1997.

BUAINAIN, A. M. et al. Quais os riscos mais relevantes nas atividades agropecuárias? O mundo rural no Brasil do século 21. Brasília: EMBRAPA, 2014a, p. 135-208.

BUAINAIN, A. M. et al. Sete teses sobre o mundo rural brasileiro. O mundo rural no Brasil do século 21. Brasília: EMBRAPA, 2014b, p. 1.159-1.182.

CABRAL, José I. Sol da manhã: memória da EMBRAPA. Brasília: UNESCO, 2015.

CARVALHO, Maria Auxiliadora de; SILVA, Roberto Leite da. Intensidade do comércio agrícola no MERCOSUL. Trabalho apresentado no 47ํㅡ을 CONSO DA SOBER, 2009, Porto Alegre. Disponível em <http://www.sober.org.br/palestra/13/447.pdf>. Acesso em 24/12/2016.

CEPEA-ESALQ. Disponível em < https://www.cepea.esalq.usp.br/br/pib-do-agronegocio-brasileiro.aspx>. Acesso em 15/12/2017.

CHADDAD, Fabio. The economics and organization of Brazilian agriculture: recent evolution and produtivity gains. Amsterdam: Academic Press, 2016. 
COLE, Célio A. A cadeia produtiva do trigo no Brasil: contribuição para geração de emprego e renda. Porto Alegre: IEPE-UFR GS, 1998 (Dissertação de Mestrado).

CONAB - Companhia Nacional de Abastecimento. Disponível em <http://www. conab.gov.br/conteudos.php?a=1252>. Acesso em 2017-2018.

DELGADO, Guilherme C. Expansão e modernização do setor agropecuário no pósguerra: um estudo da reflexão agrária. Estudos Avançados. São Paulo, v. 15, n. 43, p. 157-172, 2001.

DIAS, Guilherme Leite da Silva; AMARAL, Cicely Moutinho. Mudanças estruturais na agricultura brasileira, 1980-1998. In: BAUMANN, Renato (org.). Década de transição. Rio de Janeiro: Campus/CEPAL, 2000.

EMBRAPA. EMBRAPA em números. Brasília: EMBRAPA, 2016.

FAO Food Price Index. Disponível em <www.fao.org/worldfoodsituation/FoodPricesIndex/en/>.Acesso em 19/5/2017.

FAO-FAOSTAT.Disponível em <http://www.fao.org/faostat/en/\#home>.Acesso em 19/5/2017.

FERNANDES FILHO, J. F.A política brasileira de fomento à produção de trigo, 19301990. ANAIS DO CONGRESSO BRASILEIRO DE ECONOMIA RURAL. V. I. Brasília: SOBER, 1995, p. 443-474.

FONSECA, M. B. da. Efeitos da liberação comercial sobre o agronegócio do Brasil, 1994/2004. Análise, v. 18, n. 1, p. 36-50, jan.-jun. 2007.

FUGLIE, K. O. Productivity growth and technology capital in the global agricultural economy. In: FUGLIE, K. O.;WANG, Sun L.; BALL V. E. (eds.). Productivity growth in agriculture: an international perspective. Oxfordshire: CAB International, 2012.

GASQUES, José G. et al. Produtividade total dos fatores e transformações da agricultura brasileira: análise dos dados dos censos agropecuários. In: GASQUES, José G.; VIEIRA FILHO, José E. R.; NAVARRO, Zander (orgs.). Agricultura brasileira: desempenho, desafios e perspectivas. Brasília: IPEA, 2010, p. 19-44.

GASQUES, José G. et al. Produtividade da agricultura brasileira e os efeitos de algumas políticas. Revista de Política Agrícola, v. 21 n. 3, p. 83-92, jul.-ago.-set. 2012.

GONZÁlES, B. P. La Revolución Verde en México. Agrária, n. 4, p. 40-68, 2006.

GUANZIROLI, Carlos E. Agricultura familiar e reforma agrária no século XXI. São Paulo: Garamond, 2001.

HELFAND, Steven M.; REZENDE, Gervázio Castro de. Brazilian agriculture in the 1990s: impact of the policy reforms. Discussion Paper. Brasilia/Rio de Janeiro, IPEA, n. 98, 2001.

HOFFMANN, R.; NEY, M. G. Estrutura fundiária e propriedade agrícola no Brasil, grandes regiões e unidades da Federação. Brasília: MDA, 2010.

IBGE. Censos agropecuários. Disponível em <https://www.ibge.gov.br/estatisticas-novoportal/economicas/agricultura-e-pecuaria/9827-censo-agropecuario.html >. Acesso em 28/10/2018.

IBGE. Estatísticas do século XX. Disponível em <www.ibge.gov.br>. Acesso em 28/10/2018. 
IBGE-SIDRA. Disponível em < https://sidra.ibge.gov.br/home/ipp/brasil>.Acesso em 28/10/2018.

IPEADATA. Disponível em <www.ipeadata.gov.br/>. Acesso em 28/10/2018.

KLEIN, Herbert S.; LUNA, Francisco V. Feeding the world: Brazil's transformation into a modern agricultural economy. Cambridge: Cambridge University Press, 2019.

MAPA. Disponível em <www.agricultura.gov.br>. Acesso em 28/10/2018.

MARTHA JR., G. B.; CONTINI, Elisio; ALVES, Eliseu. EMBRAPA: its origins and changes. In: BAER, Werner (ed.). The regional impact of national policies: the case of Brazil. Cheltenham (UK): Edward Elgar Publishing, 2012, p. 204-226.

MARTINS, J. S. A militarização da questão agrária no Brasil. Petrópolis:Vozes, 1985.

MELO, Fernando B. Homem de. Composição da produção no processo de expansão da fronteira agrícola brasileira. Revista de Economia Política, v. 5, n. 1, p. 86-111, jan.-mar. 1985.

MENGEL, A. Modernização da agricultura e pesquisa no Brasil: a Empresa Brasileira de Pesquisa Agropecuária, EMBRAPA. Rio de Janeiro: UFRJ, 2015 (Tese de Doutorado).

MINISTÉRIO da Agricultura, Pecuária e Abastecimento. Comércio exterior da agropecuária brasileira. Brasília, 2012.

MUELLER, Charles; MARTINE, George. Modernização agropecuária, emprego agrícola e êxodo rural no Brasil - a década de 1980. Revista de Economia Política, v. 17, n. 3, p. 85-104, jul.-set. 1997.

NAVARRO, Zander; CAMPOS, S. K. A “pequena produção rural” no Brasil e as tendências do desenvolvimento agrário brasileiro. Revista de Extensão Rural, v. 3, n. 1, p. 25-92, 2014.

PAIVA, Ruy. Reflexões sobre as tendências da produção, da produtividade e dos preços do setor agrícola do Brasil. In: PRADO JR., Caio et al. Agricultura subdesenvolvida. Petrópolis:Vozes, 1969, p. 167-203.

PAIVA, Ruy. Bases de uma política para a melhoria técnica da agricultura brasileira. In: PRADO JR., Caio et al. Agricultura subdesenvolvida. Petrópolis:Vozes, 1969, p. 204-261.

PAIVA, Ruy M.; SCHATTAN, Salomão; FREITAS, Claus F.T. de. Setor agrícola do Brasil. Comportamento econômico, problemas e possibilidades. São Paulo: Secretaria da Agricultura, 1973, p. 17-27.

PASTORE, Affonso Celso. A resposta da produção agrícola aos preços no Brasil. São Paulo: APEC, 1973.

PASTORE, Affonso Celso; DIAS, Guilherme L. S.; CASTRO, Manoel C. C. Condicionantes da produtividade da pesquisa agrícola no Brasil. Estudos Econômicos, v. 6, n. 3, p. 147-181, 1976.

PEIXOTO, Marcus. Extensão rural no Brasil - uma abordagem histórica da legislação. Texto para Discussão. Brasília, Consultoria Legislativa do Senado Federal, Centro de Estudos, n. 48, out. 2008.

PERKINS, John H. Geopolitics and the Green Revolution: wheat, genes and the cold war. New York: Oxford University, 1997, cap. 5. 
ROCHA, Herivelto F. Produção territorial das reformas agrárias no Brasil. Presidente Prudente: UNESP, 2013 (Tese de Doutorado).

RUIZ, Lucas Gonçalves. Uma visão geral sobre a Cédula de Produto Rural (CPR), 2015. Disponível em <http://www.migalhas.com.br/dePeso/16,MI227850,11049$\mathrm{Uma}+\mathrm{Visao}+\mathrm{Geral}+$ Sobre $+\mathrm{a}+\mathrm{Cedula}+\mathrm{de}+$ Produto + Rural $+\mathrm{CPR}>$. Acesso em 27/12/2016.

SALIS, Carmem L. G. de. Estatuto da terra: origem e (des)caminhos da proposta de reforma agrária nos governos militares. Assis: UNESP, 2008 (Tese de Doutorado).

SANTIAGO, Maura M. D.; SILVA,Valquíria da. A política de crédito rural brasileira e o endividamento do setor agrícola: antecedentes e desdobramentos recentes. Agricultura em São Paulo, v. 46, n. 2, p. 47-70, 1999.

SILVA, F. P. Modelos de financiamento da cadeia de grãos no Brasil. $2^{a}$ CONFERÊNCIA EM GESTÃO DE RISCO E COMERCIALIZAÇÃO DE COMMODITIES, 2012a, São Paulo, BM\&F.

SILVA, F. P. O crédito rural no Brasil. Animal Business Brasil, 2 (6), p. 61-66, 2012 b.

SILVA, J. G. A nova dinâmica da agricultura brasileira. Campinas: UNICAMP, 1996.

SZMRECSÁNYI, Tamás. O desenvolvimento da produção agropecuária (1930-1970). In: FAUSTO, Boris (org.). História da civilização brasileira. Tomo III. V. 4: O Brasil republicano. Rio de Janeiro: Bertrand Brasil, 1995, p. 107-207.

WORLD Bank. Brazil the management of agriculture, rural development and natural resources. Washington: World Bank, 1994 (Report n. 11.783-BR). 